\title{
Labour mobility in transnational Europe: Between depletion, mitigation and citizenship entitlements harm
}

\author{
Ania Plomien ${ }^{1}$ \\ Gregory Schwartz ${ }^{2}$ \\ ${ }^{1}$ London School of Economics and Political Science, Department of Gender Studies \\ ${ }^{2}$ University of Bristol, Department of Management
}

\begin{abstract}
:
This article examines how transnational labour mobility in combined and uneven Europe has emerged as a critical response to the problems of capitalist production and social reproduction. Analysing the interconnected mobilities of workers between Ukraine, Poland and the UK in the food production, care provision and housing construction sectors, the article examines how states benefit from lower unemployment and reduced labour shortages, employers profit from qualified and reliable workers, and households gain access to jobs and incomes. It argues that transnational labour mobility is constitutive the inherently interdependent production-reproduction processes. In this constellation, transnational labour mobility becomes a form of mitigation against depletion through social reproduction. It further argues that such a mitigation strategy is, however, unbalanced and unsustainable, as its costs and benefits are unequally distributed, forestalling resource inflows that could attenuate outflows. Therefore, harms, in particular the harm to citizenship entitlements, emerge despite labour mobility mitigating against depletion.
\end{abstract}

\section{Key words:}

labour mobility, social reproduction, depletion, citizenship entitlements, gendered harms

\section{Key messages}

- Social reproduction, capitalist production, transnational labour mobility constitute a nexus

- Labour mobility is a form of mitigation against potential depletion through social reproduction

- The structural position of the figure of the migrant leads to citizenship entitlements harm 


\section{Introduction}

Transnational labour mobility in Europe stems from and intensifies gendered struggles over the boundaries between the national and the supra-national, between social reproduction and capitalist production, and between social citizenship obligations and entitlements deriving from paid and unpaid labour. Emerging as a critical response to the inherently interconnected exigencies of social reproduction and capitalist production, several objectives converge in labour mobility, including sending and receiving governments attempting to satisfy the conflicting interests of employers and workers through migration, employment and social policies; businesses seeking lower labour costs; mobile workers pursuing better living standards; and local workers seeking livelihood strategies by either refusing to work under conditions that undermine social reproduction, or benefitting from cheaper goods and services offered by migrant labour. Moreover, the intensified pressure on the sphere of social reproduction through marketisation, individualisation and retrenchment of state support (Bakker, 2007; Fraser, 2016) increases the demand for, but lowers the capacity to engage in, social reproductive labour. This dynamic leads to depletion, wherein those engaged in social reproduction suffer resource shortfalls because outflowing resources exceed those that are inflowing (Rai et al, 2014: 87-90). For example, to compensate for falling wages and deteriorating public services, more effort is required from households in both paid and unpaid labour to maintain similar levels of well-being. Depletion can be reversed in various ways, mitigation being the most prevalent response by developing private strategies to lessen its severity (Rai et al, 2014) - a process directly connected to labour mobility. We thus ask, to what extent does labour mobility mitigate against depletion in contemporary Europe?

Depletion is affected by particular contexts of social reproduction and production. Europe's production regime is simultaneously integrated, differentiated, and unequal, with European Union (EU) regulations playing a key role within and beyond its borders ${ }^{1}$. To probe our question, we analyse the interconnected labour mobilities between Ukraine, Poland and the United Kingdom (UK) in care provision, food production, and housing construction sectors, which are key to social reproduction. We argue that while labour mobility within Europe appears to be an effective and cost-efficient mitigation strategy, its effect is limited in scope, unevenly distributed, and socially unsustainable, addressing depletion in some parts of Europe and for some groups, while exacerbating it elsewhere and for others. Further, and more importantly, we argue that whereas depletion prompts gendered harms, mitigation through labour mobility not only fails to reverse depletion, but itself generates harms. One harm in

\footnotetext{
${ }^{1}$ When referring to Europe, we include both EU member states and non-EU countries; references to the EU invoke specifically its member states and institutions.
} 
particular that such partial and market-based mitigation generates is the harm to citizenship entitlements (Rai et al, 2014: 92), emanating from stripping down the principles of full citizenship to that of mere labour power, as households, businesses and states confront labour mobility.

Our discussion begins with theorising social reproduction and capitalist production in relation to the depletion framework in the context of Europe's divergent and unequal integration. This is followed by an outline of motivations for country and sector selection. We then analyse transnational labour mobility and harm to citizenship entitlements. The article makes the following twofold contribution. First, we elaborate the gendered dynamics of social reproduction in contemporary Europe. Second, we extend the depletion framework by incorporating additional parameters: a) the inclusion of transnational labour mobility in the analysis of social reproduction and b) the integration of gendered harms as existing in a dialectical relationship with different forms of responses to depletion. By doing so, we contribute to the literature on migration by bringing it into conversation with the depletion framework, and to the literature on social reproduction by inflecting it with transnationality.

\section{Transnational social reproduction in an uneven and combined Europe}

\section{Social reproduction, capitalist production and depletion}

Theorising the intrinsic link between social reproduction and capitalist production, feminist scholars variously emphasise three areas of concern (for recent overviews see Bhattacharya, 2017; Mezzadri, 2019; Winders and Smith, 2019). The first entails the biological reproduction of people - individual labour power - and work associated with motherhood. The second, which we adopt here, denotes the daily and intergenerational reproduction of the total workforce through subsistence, socialisation and care, including through transnational processes, such as migration. Expanding beyond paid and unpaid care-work and housework typically considered in global social reproduction scholarship (Truong, 1996; Kofman and Raghuram, 2015), we frame these activities as: a) entailing unpaid household production of goods, services, and leisure; b) requiring resources of time, skill, and ability; c) depending on wages, incash and in-kind state provision, and market substitutes; and d) supporting the work-readiness of current and future wage earners directly, as well as indirectly, by relieving workers from care-obligations towards dependent household members. Social reproduction, then, occurs across the household, the market, and the state; is interdependent with capitalist production; and involves transnational labour mobility. The third, and broadest, conceptualisation comprises the reproduction of the social system. As a totality, social reproduction encompasses all three levels: containing paid and unpaid care work, but 
extending to the wider reproduction of social relations that sustain capitalist society itself, with gender, race and class crosscutting these processes.

The key contribution of social reproduction theorising is the centrality of life-sustaining activities and their necessary but contradictory relationship to the production of surplus value in capitalism. Since capitalist production is based on people's dependence on both paid and unpaid work and necessitates the existence of a sphere of life outside market relations - in which people are born, nurtured and acquire volition and skills - the 'struggles over the conditions for the reproduction of the commodity labour power' (Vogel, 2000: 163) are historically contingent. Periodic overaccumulation in capitalist production leads to diminishing investment opportunities in specific industries or localities, forcing capital and pressuring states to seek 'fixes' (Harvey, 1982), including technological changes, production restructuring, wage restraints and transformations of labour relations. The neoliberalization of states and markets (Brenner et al, 2010) has increased capital's share of surplus value, shrinking welfare provisioning and imposing a market logic onto non-market social spheres. Because of the productionreproduction interdependence, state policies aiming to fix the sphere of production have reshaped the domestic and non-commodified spheres (Elson, 1998; Elson and Cagatay, 2000). The flexibilization of labour markets, privatization of public assets, and marketisation of social services reconfigure public and private sectors such that 'capitalist market relations increasingly infiltrate social reproduction' (Bakker, 2007: 541).

Consequently, the conditions for social reproduction are subject to doubly deteriorating workwelfare relationship: in the labour market through falling wages and precarisation (Vosko, 2010; Pochet and Degryse, 2012) and in the public provision of services and benefits through a social investment logic, individualisation, conditionality, rationing, targeting, co-payment and withdrawal (van Kersbergen et al, 2014; Taylor-Gooby et al, 2017). Securing livelihood compels more people to participate in employment, including transnationally. Increased women's labour force participation over the last several decades has been driven partly by these pressures and partly by women's struggle against the industrial-era male breadwinner model dominant in Western Europe and North America (McDowell, 1991; Lewis, 1992). Yet, the liberating potential of women's employment has not been realised. The above double deterioration, the 'slow drip of change' in men's uptake of care and housework (Sullivan et al, 2018: 274) and the international transfer of reproductive work (Truong, 1996; Parreñas, 2005; Kofman and Raghuram, 2015) have generated new inequalities, reinscribing differences in caregiving disproportionately borne by women along hierarchies of gender, class, race, ethnicity and migration status. The resultant 'conflictive relationship between the imperatives of capitalism and the necessities 
of material life' (Bakker, 2007: 543) has deepened the fissures among domestic, political, economic and ecological spheres (McDowell, 1991; Elson, 1998; Elson and Cagatay, 2000; Fraser, 2016). A vicious cycle of increasing demands on social reproduction and diminishing capacity to meet social reproduction needs is created by market pressures and state absenteeism or withdrawal, obliging households and businesses to resort to private solutions in supply of a productive, willing and skilled workforce.

Rai, Hoskyns and Thomas (2014) encapsulate this process in the concept of depletion through social reproduction, whereby socially reproductive work becomes unsustainable because of greater outflows than inflows of resources. Attempts to reverse depletion can take the form of mitigation (individual strategies to minimise its consequences), replenishment (input of inflows by state and nonstate actors), and transformation (structural change, leading to gender equality and valuation of social reproduction) (Ibid: 99-100). Unaddressed, depletion results in connected gendered harms - discursive, emotional, bodily, and citizenship entitlements (Ibid: 91-92). We consider harm to citizenship entitlements particularly apposite for unpacking how transnational labour mobility interacts with the depletion-mitigation dialectic.

The concept of citizenship highlights an inclusion-exclusion tension, demarcating members entitled to claims on the state from non-members with partial or discretionary entitlements (Marshall, 1950; Lister, 1997). Social citizenship, in particular, underscores the gendered character of the workwelfare relationship, wherein paid labour renders citizens entitled to state provisioning, while unpaid work and care confers second-class citizenship (Pateman, 1989; Lister, 1997). Harm to citizenship entitlements denotes here processes marking particular groups as economic 'non-contributors' unworthy of the entitlements carried with citizenship, for example those performing unpaid socialreproductive work have an inferior status because social reproduction and the resultant depletion go unacknowledged (Rai et al, 2014:92). Social reproduction is also commodified and market-based as well as market dependent. However, market-dominated economies carry a risk of entitlement failure (Drèze and Sen, 1991; Elson and Cagatay, 2000), because market participation does not guarantee the conversion of people's resources into life's necessities. A status change from unproductive-excluded to productive-included might not thus automatically bring the fulfilment of entitlements. For these reasons we extend harm to citizenship entitlements to include economic 'contributors' and the realisation of citizenship entitlements. Combined, citizenship entitlements signify formal status (who can exercise them), substantive attainment (what they bring), and the guarantor role of the state complicated by transnationalisation (Faist, 2014) and the inadequacy of nationally-based social citizenship for cross-border processes involved in labour mobility. 
Social reproduction in uneven and combined Europe

Contemporary Europe is economically integrated, but internally differentiated and unequal. The EUestablished four freedoms of movement (capital, goods, services, people) have shaped the single market, the Eurozone monetary Union, and the extension of internal market provisions to several nonEU countries via the European Economic Area and Deep and Comprehensive Free Trade agreements. Crucially, integration has reshaped the freedom of movement for workers and their families, and those not in employment (subject to financial means and health insurance coverage). Simultaneously, through enlargements and associations, the EU has influenced wider European integration, committing non-EU countries to EU technical, consumer and regulatory standards in exchange for preferential market access. Thus, European countries are variously embedded in the complex network of differentiated integration, being subject either to all or select EU rules (Becker and Jäger, 2012; Schimmelfennig et al, 2015).

Moreover, EU member states experience persistent gender differences in paid employment and in unpaid housework and care. Although women's employment has increased, narrowing employment gender gaps, unpaid work and care, which is estimated to comprise $17 \%$ to $31.6 \%$ of GDP (Giannelli et al, 2012), continues to be performed predominantly by women, since EU work-life balance measures have only slightly de-gendered them (Plomien, 2018; European Commission, 2019). Growing care needs for children and dependent adults remain unmet even as public expenditure and infrastructure expands (OECD, 2017; European Commission, 2018a), so the household mix of waged employment and unpaid work and care continues to vary with the levels of state support and reliance on the market. Market, in turn, develops as governments balance migration and social policies - the transnational labour supply (for households and businesses) becomes crucial for social reproduction.

This gendered diversity of Europe has been theorised in terms of welfare state, employment, care and, more recently, migration models or regimes (e.g. Lewis, 1992; Bettio and Plantenga, 2004; Williams, 2012; Erhel and Guergoat-Larivière, 2013; Lutz, 2017). Regarding employment, such approaches have focused on the changes within the historical male breadwinner and dual earner models to explain rising West European women's (especially mothers) employment through childcare and labour market flexibility measures, and falling women's employment in post-socialist Europe through the dismantling of the (fragile) work-care infrastructure (Pascall and Kwak, 2005). Concerning societal organisation of care, regime approaches have identified policy models like defamilialisation (public provision of care services) and familialisation, either explicit (public provision of paid leaves and 
benefits) or implicit (limited provision of services or benefits) (Leitner, 2003; Saraceno and Keck, 2011; Erhel and Guergoat-Larivière, 2013). In addition to the work-care axis, migration scholars have outlined how labour market needs dictate the rules for transnational labour mobility, with feminist researchers arguing for connecting migration, labour market and care regimes (Williams, 2012; Engbersen et al, 2017; Lutz, 2017).

Understanding how these complex processes interact, however, demands a more encompassing framework than regime analysis. The differences in labour and employment, unpaid work and care, and the intersection of labour mobility in these processes, are founded on diverse forms of gendered social organisation that result from particular constellations of power and social struggles forged and institutionalised in nation states within global capitalism (Gerstenberger, 2007). Waves of restructuring and regulation of global capital and national states 'build on, exploit, intensify and canalize inherited differences among (supranational, national and subnational) regulatory landscapes', constituting a variegated neoliberalisation (Brenner et al, 2010: 195). Building from the inherently interdependent and conflictive productive-reproductive relationship, we bridge the problem of social reproduction theoretically with the concept of variegated neoliberalisation (Brenner et al, 2010). Theorising social reproduction as variegated (Bakker and Gill, 2019), whereby households, culture and the economy are shaped and (re)negotiated over time, offers a fuller understanding of production-reproduction processes. This framework conceptualises variegation as co-constitutive of the regulatory transformations that define the scope and depth of social reproduction. Neoliberalisation processes exacerbate existing institutional-spatial differentiation and contribute to a cumulative, market-oriented reworking of the parameters of social reproduction, while those facing depletion can seek mitigation against it, including through labour mobility. Variegated social reproduction in contemporary Europe, thus, represents an interconnected process of transnationalisation of production and social reproduction, the neoliberalisation of states and state-involvement in social reproduction, and the inducement of depletions. Labour mobility aimed at mitigating such depletions confronts the differentiated regulation of citizenship entitlements, or their de facto failures, potentially constituting new harms.

\section{Delineating the scope of analysis}

Our analysis of the interconnected mobilities of labour between Ukraine, Poland and the UK within care provision, food production, and housing construction sectors draws on the feminist political economy tradition. We use secondary data, especially statistics, research-based reports and recent academic 
studies illustratively to construct our argument about the dynamics of social reproduction in contemporary Europe. Based on our conceptualisation of social reproduction we have selected the three sectors due to their enmeshing within the spheres of production and reproduction to form a nexus without which sustaining individuals, communities and societies is unimaginable. They straddle the unpaid-paid labour divide, from the most commodified construction sector to the predominantly uncommodified care provision. Actors in these sectors experience similar profitability or income pressures as in the rest of the economy, but because activities in them are labour-intensive, linked to subsistence and locally underpinned by gendered culture, the available cost-saving fixes for businesses and households are limited. Consequently, the care, food and housing sectors are sites of considerable labour shortages and labour mobility, with workers utilising market-based mitigation strategies to provision individual and household social reproduction needs, and businesses using migrants for improving resourcing and labour control. Finally, labour in these sectors is gendered in different ways, being predominantly feminised in care, mixed in food, and overwhelmingly masculinised in housing, as a result framing women's and men's opportunities and constraints differently, and unevenly reconstituting gender relations in Europe.

We have selected Poland, Ukraine and the UK due to significant labour mobility connecting them as either large senders or receivers (or simultaneously both) of migrant workers. Their interrelatedness is underpinned by their differential embeddedness in an integrated Europe, demarcated by the different political and economic agendas deriving from membership in or association with the EU. This process of combined and unequal political and economic development shapes these countries' scope for addressing their specific needs of production and social reproduction. Consequently, in all three countries labour mobility has been a prominent strategy, albeit featuring distinct motivations, for households, businesses and states. The relative differences between the 'peripheral' (Ukraine), 'semi-peripheral' (Poland) and 'core' (pre-Brexit UK) political economies of Europe allow us to analyse labour mobility as mitigation, and to assess its ramifications for citizenship entitlement harms.

\section{Gendered labour mobility in transnational Europe}

The political economies of Ukraine, Poland, and the UK 
Despite common global economic pressures, the distinct social and political constellations in Ukraine, Poland and the UK have created divergent gendered political economies and forms of social reproduction (see Table 1). Ukraine's and Poland's integration into world markets following the collapse of state-socialism set in motion the dissolution of their uncompetitive manufacturing, displacing large numbers of workers, especially lower-skilled women, and reshaping their gendered employment structures. De-industrialisation in the UK turned it into a leading centre of international finance, corporate legal services and high-tech manufacturing, causing extensive social re-allocations, de-skilling and re-skilling, and many more women entering employment.

Table 1: Main socioeconomic indicators for Ukraine, Poland and the UK, 2016-2018.

\begin{tabular}{|c|c|c|c|}
\hline Category & Ukraine & Poland & UK \\
\hline \multicolumn{4}{|l|}{ Demography } \\
\hline - population (million) & 42.4 & 37.9 & 66.3 \\
\hline - life expectancy (years, men / women) & $67.5 / 77.3$ & 73.9 / 81.8 & 79.5 / 83.1 \\
\hline - total fertility rate & 1.35 & 1.5 & 1.7 \\
\hline \multicolumn{4}{|l|}{ Labour Market } \\
\hline - employment (rate, 20-64, men / women) & $69.4 / 59.4$ & $78.2 / 63.6$ & $83.3 / 73.1$ \\
\hline - unemployment (rate, 15-74, men / women) & $11.1 / 7.7$ & $4.9 / 4.9$ & $4.5 / 4.2$ \\
\hline $\begin{array}{l}\text { - non-employed due to family responsibilities (\% of 'inactive' } \\
\text { working-age population, men/ women) }{ }^{1}\end{array}$ & $15 / 45.5$ & $11 / 39.9$ & $8.2 / 37.6$ \\
\hline \multicolumn{4}{|l|}{ Social Conditions } \\
\hline - GDP per capita (PPP, international dollars) ${ }^{2}$ & 9,333 & 31,336 & 45,973 \\
\hline $\begin{array}{l}\text { - social protection expenditure (\% GDP, including health, } \\
\text { excluding admin. costs) }\end{array}$ & 18.2 & 20.6 & 25.6 \\
\hline - population at risk of poverty after transfers (\%) & 23.5 & 14.8 & 18.9 \\
\hline - formal childcare $\left(\%, 0-3 /{\text { preschool })^{3}}^{3}\right.$ & $14.8 / 59$ & $10.9 / 59.4$ & $38.7 / 69.6$ \\
\hline - gender order & retraditionalised & retraditionalised & transitioning \\
\hline
\end{tabular}

Sources: Eurostat 2019; 1: for Ukraine: UKRSTAT 2018a, Table 4.2; 2: World Bank 2020; 3: for Ukraine UKRSTAT 2018b, Table 1.12

Poland's endowment of a skilled workforce and its foreign capital-dominated privatisation (incentivised by tax-breaks, discounted real estate and training subsidies) brought some industrial and skill upgrading (Bohle and Greskovitz, 2006; Drahokoupil, 2009). Simultaneously, transition-period high unemployment and labour market informality have formalised into flexibility through precarious 'junk contracts', which together with age and gender segregation have cemented inequalities (Czarzasty et al, 2014; Drahokoupil and Piasna, 2018). Ukraine started from a similar position to Poland, but oligarchic state capture resulted in low foreign direct investment, lack of industrial upgrading (Mykhnenko and Swain, 2010; Yurchenko, 2018), and the dominance of low-wage, informal and insecure employment (Williams et al, 2011). Structural changes in Britain began in the late 1970s, when profitability pressures 
in manufacturing broke the post-war Keynesian compromise with its industrial policy, training schemes and a generous welfare state (Clarke, 1988). The deregulation of the British economy has fostered the development of a flexible labour market characterised by individualised labour contracts and the deterioration of job and income security (Deakin and Wilkinson, 1991).

In all three countries, then, economic transformations have affected access to and conditions of employment, such that waged work fails to guarantee the fulfilment of the full spectrum of social reproduction needs. Furthermore, the neoliberalisation of state policy has made the extent and scope of social protection subordinate to the development of competitiveness and market growth, thus making both wages and public policy contingent on economic performance. The last three decades of economic growth have been uneven (World Bank, 2020). While growth has been consistently positive in Poland, the net outflow of profits and property incomes continues and exceeds EU transfers (Piketty, 2019). Poland's foreign capital orientation negatively impacts its welfare provisioning capacity, resulting in its net social expenditure being among the lowest in the EU. Slower economic growth in the UK has been accompanied by neoliberal policies of the 1980s-2000s that significantly curtailed social expenditure, while negative growth in 2008-2010 and post-2010 austerity policies fundamentally reordered the relationship between the state and the market in the provision of welfare in favour of the latter (Grimshaw and Rubery, 2012). Finally, Ukraine's economic growth has been both volatile and netnegative. It was one of the worst affected post-socialist economies in the 2008 global economic crisis, whose double-digit GDP growth rate decline necessitated massive public expenditure cuts required by a \$16 billion IMF stand-by loan (ILO, 2013). The 2014 political crisis and Russia's military intervention compounded these problems with rapid inflation and the collapse of investment and social services

Generating different levels of wealth (the UK is wealthier than Poland and Ukraine, respectively ranking $14^{\text {th }}, 26^{\text {th }}$ and $45^{\text {th }}$ of forty-six European nations), aggregate social protection expenditure in the three countries is, moreover, utilised in distinct ways (see Table 1). For example, Poland prioritises unemployment, poverty, and income inequality while the UK emphasizes unemployment, health and family domains (Antonelli and De Bonis, 2017), thus intervening differently in the state-markethousehold resource mix facilitating social reproduction. Family policies, in particular, mediate social reproduction across the paid-unpaid work continuum, by incentivising or disincentivising the commodification of unpaid work and workers. In Ukraine, despite a comprehensive legal gender equality framework, combining childcare with employment has become more difficult as family policies emphasise women's care leaves and benefits, disincentivising women's employment and childbearing alike and reinforcing 'neotraditionalism' (Johnson and Robinson, 2007; Hankivsky and Salnykova, 2012; 
ILO, 2013). Poland's similar re-traditionalisation of the gender order ensued from adverse labour market conditions and familialist policies unsupportive of women's financial autonomy (Saraceno and Keck, 2011; Giordano, 2019), only recently seeing better employment outcomes and childcare services (alongside pro-natalist benefits) (Plomien, 2019; Shields, 2019). The UK's mixed family policy model, which includes some childcare provisioning beside counter-measures in the form of unpaid family care contributions and fiscal arrangements benefiting male breadwinner households, marginally modifies the male breadwinner/female caregiver model (Keck and Saraceno, 2011; Giordano, 2019).

The absolute and relative differences in economic performance, labour markets and social protection, with their uneven support for paid and unpaid work and care, indicate the variegation of social reproduction across Europe. It is not simply the fact of variegation, but the relative adequacy of the mix of resources that explain why migration becomes a means of redressing insufficiencies. Just as important are the opportunities, to households and businesses, created by different state policies, and how much these policies aim to address certain social reproduction depletions.

Labour mobility flows and their determinants

Migration patterns of Polish workers to the UK and Ukrainian workers to Poland have interacted with legal structures, political-economic developments and gendered norms. In 2017 the number of workingage EU citizens in the UK was 2.6 million, comprising 7\% of the total population (compared with 1.9 million of non-EU working-age migrants) (European Commission, 2018b). Polish nationals constitute the second largest group of mobile workers in the EU (17\%, following Romanians at $21 \%)$, and have become the largest in the UK, reaching 734,000 in 2017 (nearly 28\% of working-age EU migrants) (Ibid). The number of Polish-born people in the UK has increased substantially since the 2004 EU-enlargement, peaking in excess of 900,000 in 2017 (see Figure 1). While historically Poland was not a significant migration destination, it has become one, issuing the greatest number of EU residence permits (22\%), before Germany (17\%) and the UK (16\%), the majority being employment permits, with Ukrainians receiving 662,000, nearly $88 \%$ of them in Poland (Eurostat, 2018). Polish employers' high demand for Ukrainian workers (see Figure 1) generated 1.4 million jobs (942,000 men, 504,000 women) over the course of the year (MRPiPS, 2019) or 423,000 monthly (Górny et al, 2018). 
Figure 1 Labour mobility patterns of Polish and Ukrainian workers 2007-2017

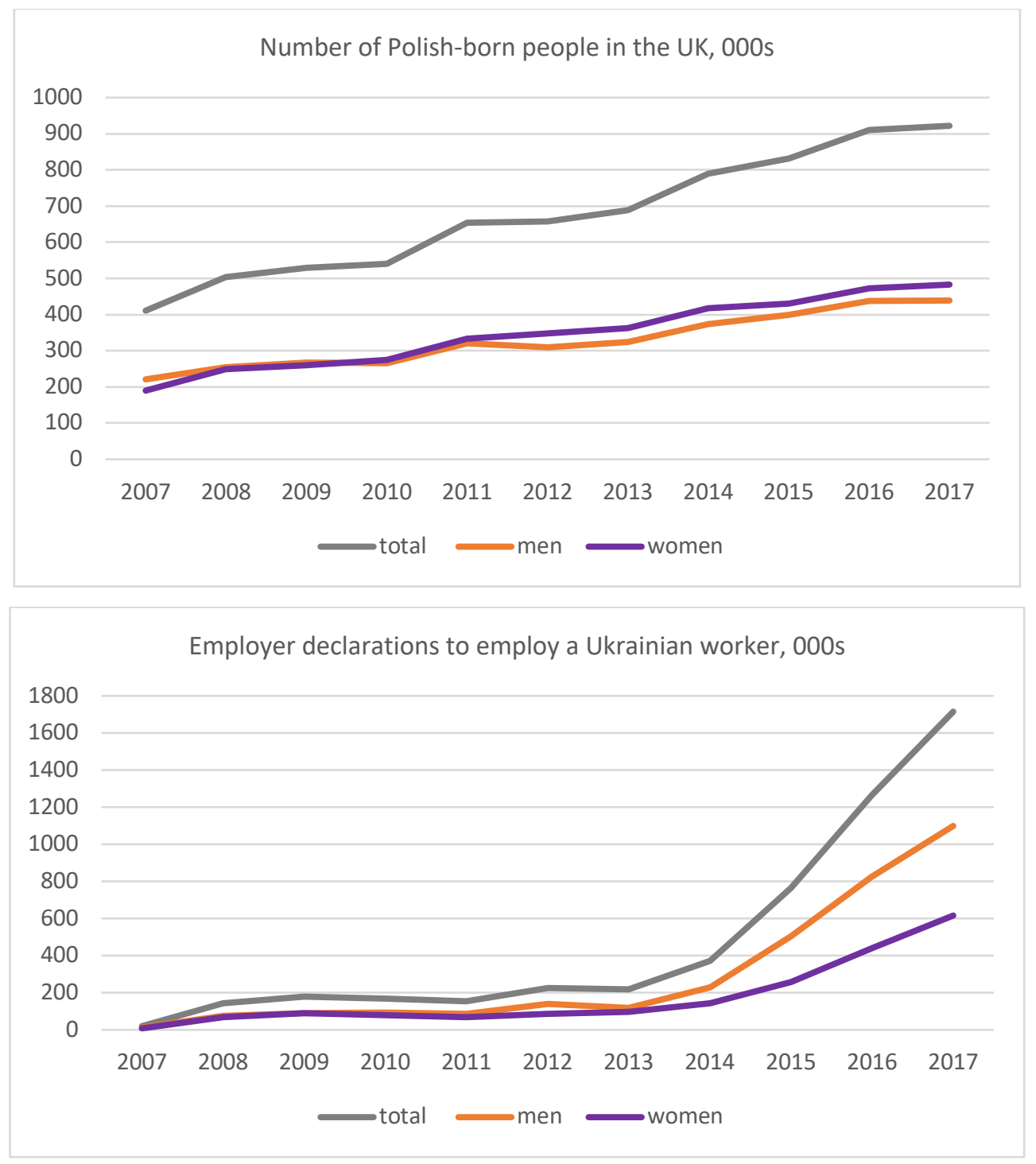

Sources: upper panel ONS (2007-2017); lower panel MRPiPS (2019)

Figure 1 demonstrates that in both destinations, women make-up a large proportion of migrants, but in the UK Polish-born women comprise a slight majority, while in Poland the faster increase of Ukrainian-born male workers has widened the gender gap from 2014 onwards. Intra-EU labour mobility patterns show (see Table 2 ) that migrants work more frequently than nationals in construction ( $11 \%$ vs. $5 \%$ ) and accommodation and food services (10\% vs. $6 \%)$. In certain sectors and occupations, migrant workers are overrepresented in jobs with labour shortages and, at the same time, there are unemployed non-migrant workers having the required skills to fill them (European Commission, 2014; 2018b). Poland, for instance, faces acute labour shortages partly because of 
emigration (European Commission, 2014; 2018b; White et al, 2018) and partly because local workers do not fill existing vacancies. Construction, transport and services sectors and agriculture, construction, and food preparation occupations all experience shortages, demanding workers for building and related trades, personal services and personal care (European Commission, 2018b). The ratio of Polish transnational to national workers (see Table 2) indicates complex mobility-employment interactions; for example, the extreme 'activities of households as employers' ratio demonstrates that employment in this sector (not experiencing shortages in Poland) is much more likely abroad than nationally; the moderately high ratio in 'human health and social work', on the other hand, experiences mobilityrelated shortages (European Commission, 2018b). Migrant workers in Poland, of whom over $90 \%$ are Ukrainian, help to prevent more severe gaps. The functioning of the gender-balanced ( $45 \%$ female) agricultural sector, for instance, depends on them, although agriculture's share in migrant employment has receded in favour of masculinised construction ( $97 \%$ male), while the feminised domestic sector (90\% female) remains small (Górny et al, 2018; Table 2). Similarly, food, construction and care sectors in the UK that rely on migrant workers, nonetheless experience recruitment problems (McGuinness and Garton Grimwood, 2017; Skills for Care, 2018; Migration Advisory Committee, 2018; Baker, 2019; Fernāndez-Reino and Renzo, 2019). The UK agriculture, forestry and fisheries sectors are heavily dependent on seasonal migrant workers, local workers holding only $1 \%$ of these jobs (Migration Advisory Committee, 2018).

High numbers of Polish workers in housing, food and care sectors seek and find employment in the UK instead of in Poland, where jobs in these sectors are left vacant or are performed by workers from Ukraine, whereas British workers do not fill them even when they have relevant skills. Various actors are involved in bringing to life this complex process through opportunities offered by transnationalisation. Households seek resources to satisfy social reproduction needs by relying on labour mobility - Ukrainian men gain construction employment in Poland and Polish men do the same work in the UK. Polish employers actively seek to fill vacancies with migrant workers because such workers 'work hard' making 'few demands' (Górny et al, 2018). Similarly, UK employers demand flexible migrant workers 'willing' to work long, unsociable hours - construction, food and care sectors in the UK target migrant workers through recruitment drives abroad, whilst employers see no alternatives to them (Jones, 2016; Migration Advisory Committee, 2018). 
Table 2 Labour shortages in the EU, the UK, and Poland.

\begin{tabular}{llr}
\hline \multicolumn{2}{c}{ Labour shortage sectors and occupations with above average shares of EU-migrant workers ${ }^{\mathbf{1}}$} & $\mathbf{2 0 1 7}$ \\
\hline EU: mobile/local workers by & activities of households as employers & $4 / 2$ \\
employment sector (\%) & accommodation and food services & $10 / 6$ \\
& construction & $11 / 5$ \\
\hline EU: occupations with highest & cleaners and helpers & 13 \\
mobile workers share (\%) & food preparation assistants & 12 \\
& mining, construction, manufacturing, transport & 10 \\
& agricultural, forestry and fisheries & 10 \\
& building and related trades & 8 \\
& personal services & 7 \\
\hline UK: occupations with high mobile & mining, construction, manufacturing, transport & 24 \\
workers share (\%) & food preparation assistants & 14 \\
& drivers and mobile plant operators & 11 \\
& personal care workers & 7 \\
\hline PL mobile/national workers ratio in & activities of households as employers & 142 \\
the same sector in Poland (\%) & accommodation and food services & 30 \\
& construction & 16 \\
& health and social work & 12 \\
\hline Change in employment share of third country nationals (TCNs) in sectors in Poland ${ }^{\mathbf{2}}$ & $\mathbf{2 0 1 4}$ & $\mathbf{2 0 1 7}$ \\
\hline PL: TCN share (\%) & agricultural, forestry and fisheries & $2.4 / 16.8$ \\
(work permits / employer & construction & $19.6 / 13$ \\
declarations) & accommodation and food services & $3.3 / 46 / 2.4$ \\
& activities of households as employers & $16.2 / 14.1$ \\
\hline
\end{tabular}

Sources: 1: EC 2018b; 2: MRPiPS (2019)

Note: Mobile workers are EU nationals, TCNs are from outside the EU.

State involvement at national and EU levels facilitates labour mobility to fill gaps generated in the labour market by structural reforms, gender realignments and EU integration. The UK opened its labour market to 2004 accession countries' workers, initially granting them limited access to social benefits and, following 12 months of employment, to the full range of entitlements (Kilkey et al, 2014). This relatively privileged regime was combined with a difficult labour market situation in Poland at the time, especially high unemployment and low pay. Poland's accession to the EU, initially helped to turn its economy around, but also created labour shortages as circular migration and emigration has structurally turned Poland into a net labour exporter (Meardi, 2012). Polish migration policy has thus primarily been oriented towards reducing labour shortages, introducing in 2006 a simplified procedure for employing foreign workers, initially in agriculture and from 2007 in all sectors. Ukraine's falling demand for vocationally trained workers and wages lagging behind inflation (Brainerd, 2010) has led to significant labour emigration to Poland, but on precarious terms. Migration regulations and the emergence of a booming temporary employment agencies industry, privileges short-term employment (up to 6 months annually or 9-month seasonal permits in agriculture, accommodation and food sectors). The majority of 
Ukrainian workers in Poland are thus in the country briefly, although a growing number desire a longer temporary (up to 3 years) or permanent residence. By 2019 nearly 180,000 Ukrainians had valid temporary (77\%) or permanent (20\%) residence permits (Urząd ds Cudzoziemców, 2019) - numbers paling in comparison to short-term and seasonal workers contributing to the Polish economy annually.

\section{Citizenship entitlement harms}

Labour mobility affords access to employment on terms not available to workers in the country of origin, but this entails incursions into citizenship rights. The formal status of Ukrainian migrants in Poland is explicitly limited and contingent on the oscillations of labour market and migration policy, which have prioritised production needs. Although an increasing proportion of Ukrainian workers gain some social citizenship rights (e.g. 441,000 Ukrainian nationals have become insured by the end of 2018 (Zakład Ubezpieczeń Społecznych, 2018)), their temporary long-hours employment, with evidence of working time and pay abuses (Górny et al, 2018), constrains their full participation in transnational life-sustaining activities. In such a legal environment, they are construed explicitly as labour inputs. From the perspective of Ukrainian migrants, the ability to work in Poland, with higher wages and better working conditions, furnishes both the immediate means of securing greater subsistence and, via remittances, benefits Ukrainian households, to satisfy the needs of social reproduction. For example, Ukrainian men in construction employment in Poland, like many migrant fathers (Kilkey et al 2014; Mahon, this issue), assume responsibilities as long-distance contributors through remittances and emotional labour. Likewise, Ukrainian women working in Poland, engage in long-distance care responsibilities towards children, grandchildren and parents left 'back home' (Pallenga-Möllenbeck, 2013). Yet the scope of that social reproduction is stunted, not only by the fact that the lower pay and longer hours of work they must accept vis-à-vis Polish workers obtains a narrower range of goods and services, but also because their exclusion from social benefits and other state transfers, limits the mix of resources for social reproduction and increases their insecurity.

Polish migration to the UK enjoys a more privileged legal position and, de jure, allows for a more encompassing exercise of citizenship rights. Polish migrants are better able to accommodate their families and social reproductive needs (Kilkey et al, 2014) than Ukrainians in Poland. The framing of migrants as formal EU citizens changes the 'incomplete' migration (of male breadwinners) to wholefamily migration (White, 2011). These special EU citizenship rights, however, are wanting, as EU mobility framework protections are economically conditional and uncertain. Reforms to UK immigration and 
welfare policy of 2014 and 2016 (restricting migrants' social benefits entitlements) signal the erosion of rights and vulnerability of EU nationals to legislation changes (Burrell and Schweneyher, 2019).

Additionally, the de facto truncation of citizenship entitlements of Poles in the UK echoes the exploitability of Ukrainians in Poland, with Polish workers often employed below their skill level in lowpaid and flexible jobs in the food, housing and care sectors (Jones, 2015; Burrell and Schweyher, 2019). Construed by employers and specialist temp agencies as units of labour with 'strong work ethic', Poles are preferred over local workers unwilling to accept food-processing employment for its 'low pay, the messiness of the job, the premium [that] there is to being on the dole' (Jones, 2015: 113). Other de facto citizenship entitlements curtailment happens when Polish workers, despite meeting immediate social reproduction needs with whole-family migrations, must negotiate hands-on filial care norms (e.g. towards ageing parents) transnationally (Ryan et al, 2009; Kordasiewicz et al, 2018).

Finally, citizenship entitlement harm emerges at a macro level, whether through short-term labour shortages in sectors crucial to social reproduction, such as healthcare, or in the long-term imbalances of the responsibilities for social reproduction between markets, states and households. Migrant remittances to Poland have been found to reduce income inequality and poverty rates, but not as effectively as welfare transfers (Giannetti et al, 2009); while remittances can serve a social protection function, being a private measure, they tend to substitute rather than complement public provision (Mina, 2019). Privileging or relying on the market renders the realisation of social citizenship uncertain for those excluded from adequate local employment, state provision or labour mobility, whether in Poland or Ukraine. Ukraine already shows signs of the kind of problems Poland is currently addressing by way of Ukrainian migrant workers.

Citizenship entitlement harms, thus, emerge in context specific ways. For individuals and households, the differences between Ukrainian workers in Poland and Polish workers in the UK the most obvious harms derive from their legal status. Substantively, however, even in conditions of formal citizenship equality, it is the social position of the mobile worker qua migrant that limits the realisation of entitlements. At the community or society level, the figure of the migrant conveys a significant structural problem, as market-based resources do not, and cannot, fulfil social requirements adequately, equitably and sustainably.

\section{Conclusion}

Transnational labour mobility emerges as a mitigation strategy against the increased likelihood of depletion, as 'resource shortfalls' arise from wage decreases, employment insecurity, and the 
dependence of state support on economic performance. The unevenness of historical experience, including differentiated immersion into world markets and variegated institutional reform, combined with the integrated European labour market presents mobile workers and households opportunities to improve living standards, businesses to address production problems, and states to facilitate both. We argue that labour mobility in a combined and uneven Europe fails to adequately address the consequences of labour market and welfare state restructuring, because opportunities opened up by markets and transnationalism are limited in scope, unevenly distributed, and socially unsustainable. By moving the resources of social reproduction in space rather than securing the means of replenishing them in place, mitigation through labour mobility denotes regressive redistribution within and between countries, addressing depletion in some parts of Europe and for some groups, while exacerbating it in other parts and for others.

Further, we suggest that labour mobility that connects people through unequal social relations, generates new and modifies existing harms. Rather than social reproduction being determined in specific locations according to locally negotiated arrangements and policies, market-led policies that preclude social entitlements connected to citizenship rights have a limited scope for redressing the depletions of social reproduction. The interconnected labour mobility in Europe is made possible by the existence of inequalities where states and employers require migrant workforces to solve the twin domestic problem of production and social reproduction. Yet, migrant workers stripped of their citizenship entitlements, being construed solely as labour power, cannot secure social reproduction of the total workforce. By not addressing the resource shortfalls that balance production and social reproduction, transnational labour mobility as a form of mitigation not only fails to redress depletion, but entrenches harm to citizenship entitlements. The harm to citizenship entitlements thus affects not just those deemed economic non-contributors (Rai et al, 2014) - as our analysis highlights, this harm arises even when economic contributions of mobile workers are the necessary condition for their access to and participation in the 'host' societies.

With this analysis we propose to extend the depletion framework conceptually by specifying its parameters in two ways. One, that in contemporary combined and unequal Europe transnational labour mobility forms a constituent part of the interconnected capitalist production/social reproduction process. Two, given our argument that mitigation is limited in scope, unevenly distributed, and socially unsustainable, responses to depletion that lack a transformation impulse will always lead to social citizenship harms. Put differently, the theoretical grasp of depletion will necessarily have to account for harms existing in a dialectical relationship with the different forms of responses to depletion. 
The Authors declare that there is no conflict of interest.

\section{Acknowledgments}

We would like to thank Shirin Rai, Beth Goldblatt and Georgina Waylen for reading and commenting on drafts of this paper, the EJPG team Petra Ahrens, Liza Mügge and Kelly Dutton for their guidance, and especially the three anonymous reviewers for their insightful suggestions on improving the article. Any omissions and shortcomings are ours alone.

\section{Bio notes}

Ania Plomien is Assistant Professor in the Department of Gender Studies at the London School of Economics and Political Science. Her research centres on the processes re/producing gender inequalities, including the gender division of labour, migration, and employment and care policy, especially in Poland, the UK and the EU.

Gregory Schwartz is Senior Lecturer in Labour and Global Transformations at the University of Bristol School of Management. His research focuses on various aspects of labour and social transformation in Eastern Europe, including workers' identities, class and subjectivity, the political economy of work and labour mobility. 


\section{References}

Antonelli, M.A. and De Bonis, V. (2017) Social spending, welfare and redistribution: A comparative analysis of 22 European countries, Modern Economy, 8(11): 1291-313.

Baker, C. (2019) NHS staff from overseas: Statistics. Briefing Paper 7783: House of Commons Library.

Bakker, I. (2007) Social reproduction and the constitution of a gendered political economy, New Political Economy, 12(4): 541-56.

Bakker, I. and Gill, S. (2019) Rethinking power, production, and social reproduction: Toward variegated social reproduction. Capital \& Class, 43(4): 503-23.

Becker, J. and Jäger, J. (2012) Integration in crisis: A regulationist perspective on the interaction of European varieties of capitalism, Competition and Change, 16(3): 169-87.

Bettio, F., and Plantenga, J. (2004) Comparing care regimes in Europe, Feminist Economics, 10(1): 85113.

Bhattacharya, T. (2017) Social reproduction theory: Remapping class, re-centering oppression, London: Pluto.

Bohle, D. and Greskovitz, B. (2006) Capitalism without compromise: Strong business and weak labor in Eastern Europe's new transnational industries, Studies in Comparative International Development, 41 (1): 3-25.

Brainerd , E. (2010) Human development in Eastern Europe and the CIS since 1990. UNDP Research paper 2010/16.

Brenner, N., Peck, J. and Thodore, N. (2010) Variegated neoliberalization: Geographies, modalities pathways, Global Networks, 10(2): 182-222.

Burrell, K. and Schweyher, M. (2019) Conditional citizens and hostile environments: Polish migrants in pre-Brexit Britain, Geoforum 106: 193-201.

Clarke, S. (1988) Keynesianism, Monetarism, and the Crisis of the State. Aldershot: Edward Elgar.

Czarzasty, J., Gajewska, K. and Mrozowicki, A. (2014) Institutions and strategies: Trends and obstacles to recruiting workers into trade unions in Poland, British Journal of Industrial Relations, 52(1): 11235.

Deakin, S., Wilkinson, F. (1991) Social policy and economic efficiency: The deregulation of the labour market in Britain, Critical Social Policy, 11(33): 40-61.

Drahokoupil, J. (2009) The politics of the competition state: The agents and mechanisms of state transnationalization in Central and Eastern Europe, in L. Bruszt and R. Holzhacker (eds), The 
transnationalization of economies, states, and civil societies: New challenges for governance in Europe, New York: Springer.

Drahokoupil, J. and Piasna, A. (2018) What is behind low wages in Central and Eastern Europe?, PostCommunist Economies, 3(3): 1-19.

Drèze, J. and Sen, A. (1991) Public action for social security: Foundations and strategy, in E. Ahmad, J.

Drèze, J. Hills and A. Sen (eds) Social security in developing countries, Oxford: Oxford University Press.

Elson, D. (1998) The economic, the political and the domestic: Businesses, states and households in the organisation of production, New Political Economy, 3(2): 189-208.

Elson, D. and Cagatay, N. (2000) The social content of macroeconomic policies, World Development, 28(7): 1347-64.

Engbersen, G., Leerkes, A., Scholten, P. and Snel, E. (2017) The intra-EU mobility regime: Differentiation, stratification and contradictions, Migration Studies, 5(3): 337-55.

Erhel, C. and Guergoat-Larivière, M. (2013) Labor market regimes, family policies, and women's behavior in the EU, Feminist Economics, 19(4): 76-109.

European Commission (2019) Report on equality between women and men in the EU. Luxembourg: Publications Office of the EU.

European Commission (2018a) Barcelona objectives. Luxembourg: Publications Office of the EU.

European Commission (2018b) Annual report on intra-EU labour mobility. Luxembourg: Publications Office of the EU.

European Commission (2014) Mapping and analysing bottleneck vacancies on the EU labour markets. Available: http://ec.europa.eu/social/BlobServlet?docld=12625\&langld=en [31 May 2019].

Eurostat (2019) Population and social conditions and ENP-EAST databases. Available:

https://ec.europa.eu/eurostat/data/database and

https://ec.europa.eu/eurostat/web/european-neighbourhood-policy/enp-east/data/database [15 Dec 2019]

Eurostat (2018) First residence permits issued in the EU Member states remain above 3 million in 2017. Newsrelease 166/2018.

Faist, T. (2014) On the transnational social question: How social inequalities are reproduced in Europe, Journal of Eruopean Social Policy, 24(3): 207-22.

Fernāndez-Reino, M. and Rienzo, C. (2019) Migrants in the UK labour market: An overview. Migration Observatory Briefing. 
Fraser, N. (2016) Contradictions of capital and care, New Left Review, 100 (July/Aug): 99-117.

Gerstenberger, H. (2007) Impersonal power: History and theory of the bourgeois state, Leiden: Brill.

Giannelli, G. C., Mangiavacchi, L. and Piccoli, L. (2012) GDP and the value of family caretaking: how much does Europe care?, Applied Economics, 44(16): 2111-31.

Giannetti, M., Federici, D., \& Raitano, M. (2009) Migrant remittances and inequality in Central-Eastern Europe, International Review of Applied Economics, 23(3): 289-307.

Giordano, C. (2019) The role of gender regimes in defining the dimension, the functioning and the workforce composition of paid domestic work, Feminist Review, 122(1): 95-117.

Górny, A., Kaczmarczyk, P., Szulenka, M., Bitner, M., Okólski, M., Siedlecka, U. and Stefańczyk, A. (2018) Imigranci w Polsce w kontekście uproszczonej procedury cudzoziemców. OBM/UW/WiseEuropa: Warszawa.

Grimshaw, D., \& Rubery, J. (2012) The end of the UK's liberal collectivist social model? The implications of the coalition government's policy during the austerity crisis, Cambridge Journal of Economics, 36(1): 105-26.

Hankivsky, O. and Salnykova, A. (2012) Gender, politics and society in Ukraine. Toronto: University of Toronto Press.

Harvey, D. (1982) The limits to capital: University of Chicago Press.

ILO (2013) Decent work country profile: Ukraine. Geneva: ILO.

IMF (2018) World Economic Outlook Database. Available: https://www.imf.org/external/pubs/ft/weo/2018/02/weodata/index.aspx [15 Dec 2019]

Johnson, J.E., and J.C. Robinson (2007) Living gender after communism. Bloomington: Indiana University Press.

Jones, K. (2014) 'It was a whirlwind. A lot of people made a lot of money': The role of agencies in facilitating migration from Poland into the UK between 2004 and 2008, Central and Eastern European Migration Review, 3(2): 105-25.

Kilkey, M., Plomien, A. and Perrons, D. (2014) Migrant men's fathering narratives, practices and projects in national and transnational spaces: Recent Polish male migrants to London, International Migration, 52(1): 178-91.

Kofman E and Raghuram P (2015) Gendered migrations and global social reproduction, Basingstoke: Palgrave Macmillan. 
Kordasiewicz, A., Radziwinowiczówna, A., \& Kloc-Nowak, W. (2018). Ethnomoralities of care in transnational families: Care intentions as a missing link between norms and arrangements, Journal of Family Studies, 24(1): 76-93

Leitner, S. (2003) Varieties of familialism. The caring function of the family in comparative perspective, European Societies, 5(4): 353- 75.

Lewis, J. (1992) Gender and the development of welfare regimes, Journal of European Social Policy, 2(3): 159-73.

Lister, R. (1997) Citizenship: Feminist perspectives, Basingstoke: Macmillan.

Lutz, H. (2017) Care as a fictitious commodity. Reflections on the intersections of migration, gender and care regimes, Migration Studies, 5(3): 356-68.

Mahon, R. (2020) Redressing harms to migrant domestic workers: Global and regional spaces. European Journal of Politics and Gender, [this issue \#pages\#].

Marshall, T. H. (1950) Citizenship and social class and other essays, Cambridge: Cambridge University Press.

McDowell, L. (1991) Life without father and Ford: The new gender order of post-Fordism, Transactions of the Institute of British Geographers, 16(4): 400-419.

McGuinness, T. and Garton Grimwood, G. (2017) Migrant workers in agriculture. Briefing Paper 7987: House of Commons Library.

Meardi, G. (2012) Social failures of EU enlargement: A case of workers voting with their feet, London: Routledge.

Mezzadri, A. (2019) On the value of social reproduction, Radical Philosophy, 2.04.

Mina, W. (2019) Diaspora and government welfare spending: Do migrant remittances increase public social protection? Economic Notes, 48(3): 1-18.

Migration Advisory Committee (2018) EEA-workers in the UK labour market: annexes. https://assets.publishing.service.gov.uk/government/uploads/system/uploads/attachment dat a/file/695111/MAC ANNEXES FINAL - Interim Update v4.pdf [15 Dec 2019]

MRPiPS (Ministerstwo Rodziny Pracy i Polityki Społecznej) (2019) Zatrudnianie cudzoziemców w Polsce. Available: https://psz.praca.gov.pl/rynek-pracy/statystyki-i-analizy/zatrudnianie-cudzoziemcoww-polsce [15 Dec 2019]

Mykhnenko, V. and Swain, A. (2010) Ukraine's diverging space-economy: The Orange Revolution, postsoviet development models and regional trajectories, European Urban and Regional Studies, 17(2): 141-65. 
OECD (2017) Health at a Glance 2017: OECD Indicators, Available:

https://doi.org/10.1787/health glance-2017-en [31 May 2019].

ONS (Office for National Statistics) (2007-2017) UK population by country of birth, 2007-2017. Available: https://www.ons.gov.uk/peoplepopulationandcommunity/populationandmigration/internation almigration/datasets/populationoftheunitedkingdombycountryofbirthandnationality [31 May 2019].

Palenga-Möllenbeck (2013) Care chains in Eastern and Central Europe: Male and female domestic work at the intersections of gender, class, and ethnicity, Journal of Immigrant \& Refugee Studies, 11(4): 364-83.

Parreñas R (2005) Long distance intimacy: Class, gender and intergenerational relations between mothers and children in Filipino transnational families, Global Networks, 5(4): 317-36.

Pascall, G. and Kwak, A. (2005) Gender regimes in transition in central and eastern Europe, Bristol: Polity Press .

Pateman, C. (1989) The disorder of women. Cambridge: Polity Press.

Piketty, T. (2019) 2018, the year of Europe. Available: https://www.lemonde.fr/blog/piketty/2018/01/16/2018-the-year-of-europe/ [08 July 2019]. Plomien, A. (2018) EU social and gender policy beyond Brexit: Towards the European Pillar of Social Rights, Social Policy and Society, 17(2): 281-96.

Plomien, A. (2019) Gender inequality by design: Does successful implementation of childcare policy deliver gender-just outcomes?, Policy and Society, 38(4): 643-62.

Pochet, P. and Degryse, C. (2012) The programmed dismantling of the European Social Model, Intereconomics, 47(4): 212-17

Rai, S. M., Hoskyns, C. and Thomas, D. (2014) 'Depletion', International Feminist Journal of Politics, 16(1): 86-105.

Ryan, L., Sales, R., Tilki, M., Siara, B. (2009) Family strategies and transnationa migration: Recent Polish migrants in London, Journal of Ethnic and Migration Studies, 35(1): 61-77.

Saraceno, C. and Keck, W. (2011) Towards an integrated approach for the analysis of gender equity in policies supporting paid work and care responsibilities, Demographic Research, 25(11): 371-405.

Schimmelfennig, F., Leuffen, D. and Rittberger, B. (2015) The European Union as a system of differentiated integration: Interdependence, politicization and differentiation, Journal of European Public Policy, 22(6): 764-82. 
Shields, S. (2019) The paradoxes of necessity: fail forwards neoliberalism, social reproduction, recombinant populism and Poland's 500Plus policy, Capital \& Class, 43(4): 653-69.

Skills for Care (2018) The state of the adult social care sector and workforce in England. Accessed: www.skillsforcare.org.uk/stateof [31 May 2019]

Sullivan, O., Gershuny, J., and Robinson, J. P. (2018). Stalled or uneven gender revolution? A long-term processual framework for understanding why change is slow, Journal of Family Theory \& Review, 10(1): 263-79.

Taylor-Gooby, P., Leruth, B., \& Chung, H. (eds.) (2017) After austerity: Welfare state transformation in Europe after the great recession, Oxford University Press.

Truong, T. (1996) Gender, international migration and social reproduction: Implications for theory, policy, research and networking, Asian and Pacific Migration Journal, 5(1): 27-52.

UKRSTAT (State Statistics Service of Ukraine) (2018a) Economic activity of population in Ukraine 2017. Kyiv: SSSU.

UKRSTAT (2018b) Doškilna osvita v Ukraïni, 2017. Kyiv: SSSU.

Urząd ds Cudzoziemcow (2019) Raport na temat obywateli Ukrainy wg stanu na dz 01.01.2019.

Available: https://udsc.gov.pl/statystyki/raporty-specjalne/biezaca-sytuacja-dotyczaca-ukrainy/ [15 Dec 2019]

Van Kersbergen, K., Vis, B., \& Hemerijck, A. (2014) The Great Recession and welfare state reform: Is retrenchment really the only game left in town?, Social Policy \& Administration, 48(7): 883-904.

Vogel, L. (2000) Domestic labor revisited, Science \& Society, 64(2): 151-70.

Vosko, L. F. (2010) Managing the margins: Gender, citizenship, and the international regulation of precarious employment. Oxford University Press.

White, A. (2011) Polish families and migration since EU accession, Bristol: Policy Press.

White, A., Grabowska, I., Kaczmarczyk, P., Slany, K. (2018) The Impact of migration on Poland: EU mobility and social change. London: UCL Press.

Williams, C. C., Round, J., \& Rodgers, P. (2011). Explaining the normality of informal employment in Ukraine: A product of exit or exclusion?, American Journal of Economics and Sociology, 70(3): 729-55.

Williams, F. (2012) Converging variations in migrant care work in Europe, Journal of European Social Policy, 22(4): 363-76.

Winders, J. and Smith, B. E. (2019) Social reproduction and capitalist production: A genealogy of dominant imaginaries, Progress in Human Geography, 43(5): 871-889. 
World Bank (2020) World Development Indicators, Available:

https://databank.worldbank.org/home.aspx [15 Dec 2019].

Yurchenko, Y. (2018) Ukraine and the empire of capital: From marketisation to armed conflict, London: Pluto Press.

Zakład Ubiezpieczeń Społecznych (2018) Jaka jest sytuacja ekonomiczno-społeczna Ukraińców w Polsce? Konferencja 27.11.2018. Warszawa. Available: https://www.zus.pl/konferencjaukraina [31 May 2019]. 